\title{
Błogosławiona, któraś uwierzyła... Wiara życia i wiara wiedzy
}

Inspiracją do podjęcia tematu wiary była przeczytana przeze mnie niedawno książka współczesnego pisarza amerykańskiego, Roda Drehera, pt. Opcja Benedykta ${ }^{1}$. Również ja sam, po wielu latach pracy dydaktycznej, doszedłem do przekonania, że w dzisiejszym świecie postmodernistycznym wiara, jako rodzaj poznania umysłowego, jest deprecjonowana i uważa się ją we współczesnych mediach za wiedzę irracjonalną. Zgadzam się z Rodem Dreherem, że lekceważenie wiary jako naturalnej zasady poznawczej świadczy o swoistym nieuctwie. Zresztą pisarz ten dochodzi do trafnych spostrzeżeń w ocenie współczesnej kultury i pisze wprost: „Najlepszą metodą stworzenia generacji pozbawionych celu nieuków, którzy nie mają poczucia obowiązku wobec nikogo prócz siebie samego, jest pozbawić ich wiedzy o przeszłości.

W XX wieku wszystkie totalitarne rządy wiedziały, że kontrolowanie dostępu do pamięci kulturowej jest konieczne, aby zyskać i zachować panowanie nad ludźmi. Dziś na współczesnym Zachodzie to nie dyktatorzy odbierają nam pamięć kulturową. To my sami, niczym zadowolone, poszukujące przyjemności klony z Nowego wspaniałego świata, przestaliśmy się zajmować prze-

1 R. Dreher, Opcja Benedykta. Jak przetrwać czas neopogaństwa?, tłum. M. Samborska, Kraków 2018. 
szłością, ponieważ tłumi naszą zdolność do pożądania rozkoszy w teraźniejszości”’.

Szukanie więc tylko własnych przyjemności prowadzi do lekceważenia wiary, która wymaga rozumienia. Taka kultura, która chce budować doczesność tylko na przyjemnościach, prowadzi wprost do barbarzyństwa ${ }^{3}$.

Nie można utożsamiać wiary z religią, ponieważ wiara jest podstawową sprawnością poznawczą człowieka. Wszystkie twierdzenia, jakie wynikają z naturalnego poznania rozumowego, są twierdzeniem wiary. Również współczesna epoka, nazwana ponowoczesnością, posługuje się wiarą i jej kreatorzy wypowiadają twierdzenia wiary: „Totalitaryzmom i ponowoczesności wspólne jest pragnienie urządzenia świata, w którym ludzie będą żyli jak wyrafinowane zwierzęta, ciesząc się pełnym korytem i drobnymi przyjemnościami, i nie będą szukali niczego poza tym. Oba te porządki wierzą, że dysponują nauką zdolną rozwiązać problemy, które zmuszały nas do wyjścia poza siebie; sądzą też, że znalazły sposób na zapewnienie wszystkim trwałego szczęścia"4.

\section{Objąć świat wiarą i rozumem}

Wiedza wiary, czyli znajomość prawd wiary, jak też rozumienie wiary jako wartości egzystencjalnej, są potrzebne, ale nie wy-

2 Tamże, s. 201.

3 Dreher w swojej książce cytuje prorocze słowa Philipa Rieffa, wykładowcy w amerykańskim college'u: „Pod koniec tego bezprecedensowego rozwoju kultury, my, współcześni, osiągniemy barbarzyństwo [...] Barbarzyńcy to ludzie pozbawieni pamięci historycznej. Barbarzyństwo to prawdziwe znaczenie radykalnej współczesności. Uwolnieni od wszelkiej wiarygodnej przeszłości, zbliżamy się do barbarzyństwa, zamiast się od niego oddalać" (P. Rieff, Fellow Teachers, New York 1973, za: J. Beer, Pieties of Silence, „American Conservative", 23 X 2006. Cyt. za: R. Dreher, Opcja Benedykta, s. 200).

4 Ch. Delsol, Nienawiść do świata. Totalitaryzmy i ponowoczesność, tłum. M. Chojnacki, Warszawa 2017, s. 251. 
czerpują samej wiary do końca. Wiedza w wierze religijnej zależy od problemu uczciwości samego podmiotu wierzącego. Uczciwość intelektualna w wierze to oddzielny temat do opracowania.

Filozofia, teologia i cała kultura chrześcijańska zawsze w swojej antropologii podkreślały wiarę, uważając ją za sprawność umysłową. Do różnych przymiotów charakteryzujących ludzką naturę należy również wiara. Człowiek więcej poznaje przez wiarę. Ten sposób poznania rozumowego można określić jako poznanie nie wprost, czyli przedmiot poznania nie jest bezpośrednio dostępny mojemu rozumowi. Poznanie przez wiarę opiera się na autorytecie osoby, która relacjonuje daną prawdę. Istnieje więc w człowieku zdolność uwierzenia, to znaczy rozum, który poznaje przez wiarę, nie kwestionuje prawdziwości poznawalnego przedmiotu. Należy cenić tę zdolność poznawczą, która nie daje oczywistości poznawczej, ale pewność. Wiara jako sposób poznawania prawdy może zatem być kwestionowana dlatego, że daje tylko pewność poznawczą, a nie oczywistość.

Drugim rodzajem poznania rozumowego jest tzw. poznanie rozumowe wprost, gdy mamy do czynienia $\mathrm{z}$ oczywistością przedmiotu poznawalnego, dlatego wynik tego poznania jest oczywisty dla poznającego rozumu.

Istnieje więc wiara naturalna i nadprzyrodzona. Jeden i drugi rodzaj poznania przez wiarę nie wyklucza rozumu, ale go wzbogaca i otwiera na to, co go przekracza.

Wartość naszego człowieczeństwa mierzy się też religijnością. Oprócz wiary naturalnej istnieje też wiara religijna, ponieważ do definicji bycia człowiekiem należy również religijność. Wiara w Boga nie pomniejsza zdolności poznawczej człowieka, ale ją ubogaca i otwiera na transcendencję.

W człowieku istnieje pokusa ubóstwienia siebie. Czasy, w jakich przyszło nam żyć, są tego dowodem, ponieważ dzisiaj liczą się tylko przyjemność i moje „ja”. Często ludzie, którzy deklarują się jako niewierzący, uważają się za tych, którzy opierają swoje poznanie tylko na rozumie. Na temat Boga często dumnie 
oświadczają, że są ateistami. Taki sposób deklarowania swojej niewiary sugeruje, jakoby ateizm był czymś racjonalnym, a wiara w Boga czymś irracjonalnym. Niewiara w Boga też jest twierdzeniem wiary. Jeden twierdzi, że wierzy w Boga, a drugi wierzy, $\dot{z}$ e nie wierzy. Problem Boga jest problemem transcendentnym względem ludzkiego rozumu. Istnieje więc wiara religijna jako pozytywna odpowiedź człowieka i wiara w niewiarę.

\section{Wiara religijna}

Wiara religijna przejawia się między innymi w liturgii, a przecież „żadna liturgia nas nie zbawi. Uczynić to może jedynie przemiana serca. Liturgia jest konieczna w praktykach religijnych, aby maksymalnie wykorzystać ich potencjał, ale sama nie wystarczy. Tak jak odegranie koncertu Bacha nic nie da głuchemu. Jeśli ciało wyznawcy oddaje cześć Bogu, ale jego serce i myśli są gdzie indziej, czy z jego modlitwy wyniknie coś dobrego? Chrześcijanin ma wyznawać wiarę całym sobą. Potrzeba wiary i rozumu, by go właściwie uformować i uczynić z niego ucznia"s.

Człowiek nie obejmie więc całego świata, który poznaje tylko rozumem, ale i wiarą religijną. Ona z kolei jest otwarta na dobro i piękno. „Pierwsi chrześcijanie - jak pisze Dreher - nawracali innych nie ze względu na argumenty bardziej przekonujące niż argumenty religii pogańskich, ale dlatego, że ludzie dostrzegli w nich i w ich wspólnotach coś pięknego i dobrego - i tego zapragnęli. A to pragnienie doprowadziło ich do Prawdy"6.

Właściwie rozumiana wiara religijna zawsze rozwija i podnosi wartość samego człowieka.

\footnotetext{
5 R. Dreher, Opcja Benedykta, s. 151.

6 Tamże, s. 157.
} 


\section{Wiara biblijna}

Dla człowieka Biblii wiara była postawą właściwą i nieodzowną w jego życiu. Zajmowanie się Bogiem było czymś oczywistym, a kwestionowanie Jego istnienia uznawano za nierozważne. Ludzkie istnienie było w pełni od Boga zależne, dlatego człowiek zawsze liczył się z Bogiem. Psalmista nazywa wprost głupim tego człowieka, który kwestionuje istnienie Boga: „Mówi głupi w swoim sercu: «Nie ma Boga». Oni są zepsuci, ohydne rzeczy popełniają, nikt nie czyni dobrze. Pan spogląda z nieba na synów ludzkich, badając, czy jest wśród nich rozumny, który szukałby Boga"7 (Ps 14,1-2). Szukanie Boga i życie Bogiem było czymś rozumnym i godnym człowieka. Obserwując dzisiaj życie wielu ludzi, można powiedzieć, że wyznają coś przeciwnego. Ich zdaniem niemądrze jest wierzyć w Boga, a rozumność utożsamiana jest przez wielu z postawą ateistyczną. Podobnie było też w historii chrześcijaństwa, na przykład „w średniowieczu - jak pisze o. prof. Andrzej Napiórkowski - człowiek musiał się tłumaczyć ze swojej niewiary. Dzisiaj natomiast, w coraz bardziej sekularyzującej się Europie, trzeba się często tłumaczyć ze swojej chrześcijańskiej wiary"8.

Chrześcijanie byli, są i będą atakowani przez ludzi, którzy nie znają prawdziwego Boga, który jest miłością (por. $1 \mathrm{~J}$ 4,16), a taka miłość nigdy nie zmusza, ale pociąga ku sobie. Wiara chrześcijańska uczy, że prawdziwa miłość nie zazdrości, nie szuka swego, nie unosi się pychą, nie unosi się gniewem (por. 1 Kor 13,1-8). Współczesny świat w taką miłość nie wierzy, dlatego nienawidzi chrześcijan.

Ujmując zagadnienie wiary religijnej od strony egzystencjalnej, można stwierdzić, że poznanie przez wiarę nie staje się dla człowieka oczywiste, a więc może być przez niego zanegowane.

Teksty biblijne za Biblią Tysiąclecia, wyd. V, Poznań 2000.

8 A. Napiórkowski, Kościót w Maryi. Maryja w Kościele, Kraków-Kielce 2016, s. 72. 
Takie sądy ludzkie świadczą o tendencji do ideologizowania wiary w Boga.

Problemu Boga nie da się rozstrzygnąć drogą jedynie rozumową. Wiara chrześcijańska wyraźnie podkreśla, że jest ona przede wszystkim łaską, a więc darem samego Boga. Pełny akt wiary wymaga czynnika boskiego i ludzkiego. Wiara jako łaska przyjęta przez człowieka umożliwia opowiedzenie się po stronie Boga i poznania tego wszystkiego, co jest Bożym listem adresowanym do człowieka. „Wiara - jak pisze o. prof. Andrzej Napiórkowski - jest zarówno wielkim darem Boga dla człowieka, jak i ludzkim korelatem tego, co Bóg zbawczo w nim działa"9 .

\section{Maryja - Kobieta wierząca}

Przykładem takiej wiary angażującej Osobę Boga i człowieka jest wiara Maryi, która w ten sposób przyjmuje boskie działanie. „I jakkolwiek nie jest Ona pierwszą i jedyną wierzącą, gdyż Biblia ukazuje nam cały szereg postaci, których życie naznaczone jest wiarą, to jednak Jej wiara oznacza urzeczywistnienie, przechowywanie i rozwój Bożego planu we wszystkich wydarzeniach Jej życia" ${ }^{10}$.

Takim wydarzeniem jest też scena nawiedzenia przez brzemienną Maryję swojej krewnej Elżbiety, która też oczekiwała narodzin dziecka ${ }^{11}$. Scena ta, jak zresztą wiele innych scen biblijnych, pokazuje osobowy charakter wiary, która jest dialogiem, a treścią jej są prawdy od Boga pochodzące. Wiara dla tych świętych kobiet była treścią ich życia. One mówiły pełnym językiem wiary, czyli była to wiara wiedzy i wiara życia. Dzieliły się świadomością posiadania Boga. Dzielić się z drugim człowiekiem posiadaniem Boga, to znaczy wierzyć po chrześcijańsku. Elżbieta

\footnotetext{
9 Tamże, s. 12.

10 Tamże.

11 Łk 1,39-56.
} 
w swoim wyznaniu uświadomiła sobie, że Maryja przyniosła jej Zbawiciela: „Gdy Elżbieta usłyszała pozdrowienie Maryi, poruszyło się dzieciątko w jej łonie, a Duch Święty napełnił Elżbietę. Wydała ona głośny okrzyk i powiedziała: «Błogosławionaś Ty między niewiastami i błogosławiony jest owoc Twojego łona. A skądże mi to, że Matka mojego Pana przychodzi do mnie?»" (Łk 1,41-43). Maryi nie dziwi jej radość i zapytanie: „Skądże mi to”. Na to dzielenie się Bogiem przez Elżbietę Maryja odpowiedziała swoim Magnificat. Taki pełen wiary dialog nie dziwi i nie jest czymś idealnym, ale realnym dla człowieka, który przyjmuje postawę wiary jako sposób na życie i spełnienie się. To nie jest tylko dodatek do życia, jak często dzisiaj ludzie traktują wiarę w Boga, który w pełni daje się poznać człowiekowi w Jezusie Chrystusie.

Święty Jan Bosko te prorocze słowa wypowiedziane pod natchnieniem Ducha Świętego przez św. Elżbietę wyjaśnia następująco: „Tymi słowami Duch Święty pouczył, że Najświętsza Dziewica, obdarzona łaskami z nieba, została wybrana, aby ludzkości znowu przynieść to błogosławieństwo, które zostało utracone przez Ewę i przez tyle wieków było z utęsknieniem oczekiwane"12.

Wiara jest więc łaską, która umożliwia głębsze i szersze poznanie tej Prawdy, którą jest sam Bóg. Wspomniana wyżej scena nawiedzenia Elżbiety przez Maryję nie tylko ukazuje te dwie kobiety, które doświadczyły poznania Bożej Prawdy, ale widzimy, że również ich synowie w okresie prenatalnym doświadczają boskiego posłannictwa. „Nawiedzenie Elżbiety przez Maryję - jak pisze Benedykt XVI - będące następstwem rozmowy Gabriela z Maryją (por. Łk 1,26) doprowadza jeszcze przed narodzeniem do spotkania Jezusa z Janem w Duchu Świętym i w tym spotkaniu uwidacznia się jednocześnie wzajemna relacja ich posłannictw. Jezus jest młodszy, jest Tym, który przychodzi później.

12 Św. Jan Bosko, Meraviglie della Madre di Dio invocate sotto il titolo di Maria Ausiliatrice, Torino 1868. Por. Liturgia godzin, t. 2, Poznań 1984, s. 1445. 
Jednak Jego bliskość sprawia, że Jan porusza się w łonie matki, a Elżbieta zostaje napełniona Duchem Świętym (por. Łk 1,41). W ten sposób już w relacji św. Łukasza o zwiastowaniu i narodzeniu obiektywnie ukazuje się to, co Chrzciciel powie w Ewangelii Jana: «To jest Ten, o którym powiedziałem: Po mnie przyjdzie Mąż, który mnie przewyższył godnością, gdyż był wcześniej ode mnie» (J 1,30)"13.

Te Boże prawdy mogą być przez ludzi wyrażone i rozumiane dzięki wierze, która jest przede wszystkim darem samego Boga. Neopozytywistyczna mentalność współczesnych ludzi zawęża ich myślenie i ogranicza je do doczesności. To, co nie jest wprost do ogarnięcia ludzkim rozumem, nie pozwala na twierdzenie, że tego w ogóle nie ma.

Bez uwierzenia Bogu życie ludzkie traci sens, dlatego św. Jan Paweł II niestrudzenie przypominał wszystkim ludziom, którzy chcieli go słuchać, że „człowiek potrzebuje Boga, aby mógł być człowiekiem". Niełatwo jest uwierzyć, a więc przyjąć za prawdę to, co dla umysłu ludzkiego jest nie do pojęcia. Wiara w Boga i w to wszystko, co Bóg człowiekowi oznajmia w swoim Słowie, jest trudna, ponieważ nie daje możliwości widzenia. Człowiek najczęściej tego właśnie się domaga, tak jak Filip Apostoł powiedział do Chrystusa: „Pokaż nam Ojca”. Uwierzenie jest Bożą łaską, którą przyjęła Maryja i przyjmuje każdy wierzący chrześcijanin, dlatego Elżbieta nazwała Maryję błogosławioną, czyli szczęśliwą, ponieważ Ona uwierzyła Bożemu słowu.

A zatem wielkością człowieka jest uwierzenie Bogu, a nie sobie czy innym ludzkim autorytetom. Wiara Maryi jest wiarą integralną, na którą składa się nie tylko wiedza zakomunikowana przez Boga człowiekowi, ale również zaangażowanie całego Jej życia. Jej wiara jest wiarą życia i wiedzy. Pewność, jaką daje uwierzenie, płynie $z$ autorytetu Boga. Człowiek, aby móc uwierzyć, musi dać swoje fiat Bogu.

13 Benedykt XVI, Jezus z Nazaretu. Dzieciństwo, tłum. W. Szymona, Kraków 2012, s. 41. 
W nazwaniu przez Elżbietę Maryi błogosławioną z powodu uwierzenia Bogu zawiera się też rozumienie przez nią wartości egzystencjalnej i zbawczej wiary. Maryja uwierzyła w tajemnicę wcielenia, której Jej rozum nie mógł pojąć, chociaż została obdarzona przez Boga pełnią łaski, a więc uzdolniona do przyjęcia tego, co jest boskie. Musiała też dobrowolnym aktem swojej wiary uwierzyć w swoje dziewicze macierzyństwo, opierając się na słowie Bożym.

Inaczej zachował się Zachariasz, któremu wcześniej archanioł Gabriel zapowiedział narodzenie Jana Chrzciciela. Przecież znał doskonale przypadki z Pisma Świętego, choćby poczęcie będącej w podeszłym wieku Sary, która urodziła Izaaka, będąc już w sposób naturalny fizycznie niezdolną do bycia matką. Znajomość tych cudownych ingerencji Bożych nie przyczyniła się do uwierzenia w taką możliwość, dlatego Zachariasza spotkała kara, bo nie uwierzył Bogu, dla którego przecież nie ma rzeczy niemożliwych. W każdym przypadku jest potrzebna ludzka decyzja, ponieważ pedagogia Boga przejawia się w tym, że zawsze szanuje wolność każdego człowieka, którą go obdarzył. Dzięki całkowitemu zawierzeniu przez Maryję Bogu ludzkość otrzymała Zbawiciela.

Miarą łaski Bożej, którą człowiek otrzymuje, jest jego wiara. Błogosławieństwem więc nie tylko dla Maryi, ale dla całej ludzkości, stało się Jej fiat. Dzieło zbawienia zostało uzależnione od uwierzenia Maryi, która w ten sposób odpowiedziała na zbawczą wolę Boga. Uwielbiała Boga, który dokonał w Niej wielkich rzeczy, dlatego - jak pisze kard. Joseph Ratzinger - „oddajemy cześć Maryi, ponieważ Ona, Dziewica, reprezentuje wiarę jako młodość, jako nowy początek Boga w postarzałym świecie; uosabia bycie chrześcijaninem jako młodzieńczość serca, jako piękno i gotowość na to, co przyjdzie".

„Można oczywiście powiedzieć, że to sentymentalne - pisze dalej kardynał - ale może nasz świat cierpi właśnie z powodu tłumienia uczuć, nie tylko niezdolności do odczuwania smutku, 
ale także i radości. Takie tłumienie uczuć prowadzi do oziębłości ducha i zdziczenia serca" ${ }^{\prime 14}$.

\section{Wiara życia}

Wiara Maryi buduje i rozwija wiarę w każdym chrześcijaninie, dlatego że ten czerpie wzorce od Błogosławionej Dziewicy, która wielbiła Boga, a więc wykonywała czynności kultowe przejawiające się w Jej emocjach skierowanych całkowicie do Boga. Wielbiła Boga, a więc odpowiadała całym swoim jestestwem na te dobrodziejstwa, które od Niego otrzymała.

Cześć oddawana Najświętszej Dziewicy wynika z jej dojrzałej wiary, która staje się mądrością serca i wzorem do naśladowania. Taki człowiek jak Maryja, który całkowicie zaufał Bogu, jest piękny. Takie piękno przejawia się choćby w majowym nabożeństwie poświęconym Maryi. Ta forma nabożeństwa maryjnego łączy pobożność naturalną i ją przemienia. „W Maryi ziemia - jak pisze kard. Ratzinger - otrzymała ludzką postać, co więcej, twarz chrześcijańską, twarz Matki Jezusa. W zwróceniu się do Niej pobożność naturalna przemienia się $\mathrm{w}$ wiarę, $\mathrm{w}$ spotkanie $\mathrm{z}$ historią Boga w człowieku, która w życiu Maryi wydaje prawdziwy owoc: wcielenie Boga. W ten sposób można śmiało powiedzieć, że w Maryi pojednane zostały wiara i naturalna pobożność. [...] Tłumienie takiego rodzaju religii naturalnej oznacza zniszczenie otwartości ludzkiego serca na Chrystusa i tym samym odcięcie ludzkich korzeni wiary"15. Wiara życia, którą posiadała w pełni i którą żyła Matka Najświętsza, sprawiła, że Maryja nie tylko „W szczególny sposób uosabia jedność Starego i Nowego Testamentu, ale łączy także religię naturalną i wiarę. Związek ten nie przemawia przeciwko oddawaniu czci Maryi, lecz, przeciwnie,

${ }_{14}$ J. Ratzinger, Szukajcie tego, co w górze, tłum. M. Rodkiewicz, Kraków 2007, s. 71.

15 Tamże, s. 72. 
jest jedną z najważniejszych przesłanek jej kultu, ponieważ odpowiada historycznemu znaczeniu Matki Pana. Ona jest - jak sformułowali to ojcowie Kościoła - chrześcijańską ziemią, która nosiła Chrystusa. Dzięki Niej pobożność naturalna otrzymała twarz i historię, która ma swój koniec w Chrystusie. W ten sposób naturalna pobożność została ochrzczona. Jej prawda ujrzała światło i może teraz w towarzystwie radości kwitnąć w Boskim ogrodzie wiary. W przestrzeni maryjnej pobożność naturalna może się bez obaw rozwijać, ponieważ w adoracji Matki Pana stała się w pełni chrześcijańska"16.

Pobożność Maryi wypływa z Jej wiary, a ta z kolei angażuje całe Jej życie. Nabożeństwo maryjne powinno wypływać $\mathrm{z}$ wiary, w którą jest zaangażowane całe życie ludzkie, a jednocześnie taka wiara wzmacnia, rozwija i pogłębia życie wierzącego. „W nabożeństwie maryjnym - pisze Joseph Ratzinger - nie ma rozmyślań nad tym wszystkim [wpływem pobożności naturalnej i pogaństwa na wiarę chrześcijańską - S.K.]; ono jest po prostu związane $\mathrm{z}$ wewnętrznym instynktem wiary. I ponieważ w nim niezbywalny posag religii naturalnej stał się chrześcijański, ma ono w sobie coś z radości, ciepła i nieskrępowanego optymizmu"17.

\section{Wiara wiedzy i wiara życia}

Jedność tych dwóch rodzajów wiary religijnej wyraźnie widać w scenie zwiastowania. To orędzie, które archanioł Gabriel przekazuje Maryi, jest objawieniem boskich planów zbawienia. To, co Maryja od niego słyszy, nie było możliwe do pojęcia przez Jej ludzki rozum. Choć Boży wysłannik oświadcza Jej, że to Bóg Ją wybrał i wyposażył w nadprzyrodzoną zdolność poznawczą, Ma-

\footnotetext{
16 Tamże, s. 74.

17 Tamże, s. 75.
} 
ryja jednak nie traci swojej naturalnej zdolności poznawczej jako istoty stworzonej przez Niego i dlatego zadaje pytanie: „Jak to się stanie?". Takie pytanie jest na miejscu i świadczy tylko o wolności w rozumieniu i przyjęciu tego orędzia, które bezpośrednio pochodzi od Boga. Ten dialog Maryi z archaniołem Gabrielem wyraźnie tłumaczy trójetapowość odpowiedzi, jakiej udzieliła Bożemu wysłannikowi. Pięknie i klarownie wyjaśnia to Benedykt XVI w cytowanej wyżej książce.

„W odpowiedzi Maryi - pisze papież senior - do której teraz dochodzimy, wyróżnić można trzy etapy. Pierwszą reakcją na pozdrowienie anioła jest zatrwożenie i zamyślenie. Jej reakcja jest inna niż Zachariasza. O nim czytamy: «Strach padł na niego» (Łk 1,12). W przypadku Maryi pierwsze słowa są podobne (zmieszała się), potem jednak nie było już strachu, lecz wewnętrzne rozważanie pozdrowienia anioła. Zastanawia się (prowadzi dialog sama ze sobą), co miałoby znaczyć to pozdrowienie posłańca Bożego. Już tutaj pojawia się więc charakterystyczny rys obrazu Matki Jezusa, który w podobnych sytuacjach w Ewangelii spotykamy jeszcze dwa razy: wewnętrzne mocowanie się ze Słowem (por. Łk 2,19.51).

Maryja nie pozostaje w swej reakcji przy początkowym zaniepokojeniu bliskością Boga w Jego aniele, lecz usiłuje zrozumieć. Okazuje się więc niewiastą odważną, która nawet w obliczu czegoś niesłychanego zachowuje się roztropnie. Jednocześnie widzimy ją jako niewiastę prowadzącą bogate życie wewnętrzne: kontroluje swe serce i rozum oraz próbuje poznać kontekst i całość orędzia Bożego. W ten sposób staje się obrazem Kościoła, który rozważa słowo Boże, usiłuje zrozumieć je w całości i jego dar zachować w pamięci.

Zagadkowa jest dla nas druga reakcja Maryi: zmieszanie i rozważanie po pozdrowieniu Jej przez posłańca Bożego. Wtedy anioł oświadczył jej, że została wybrana na matkę Mesjasza. Na to Maryja stawia krótkie, zwięzłe pytanie: «Jakże się to stanie, skoro nie znam męża?» (Łk 1,34). [...] 
Poczynając od Augustyna, kwestię tę wyjaśniano w tym sensie, że Maryja złożyła ślub dziewictwa i zgodziła się na zaślubiny tylko po to, żeby mieć opiekuna swego dziewictwa. Rekonstrukcja ta jest jednak całkowicie obca dla świata judaizmu za czasów Jezusa i wydaje się niewyobrażalna w tym kontekście. Co więc znaczą te słowa? Nowożytna egzegeza nie znalazła przekonującej odpowiedzi. [...]

Zdanie to pozostaje więc nadal zagadką - albo powiedzmy raczej: tajemnicą. [...]. Anioł zapewnia Ją, że matką zostanie nie w normalny sposób, po przyjęciu do domu przez Józefa, lecz przez to, że «moc Najwyższego okryje cieniem», przez przyjście Ducha Świętego, i stwierdza z mocą: «Dla Boga bowiem nie ma nic niemożliwego» (Łk 1,37).

Następuje wtedy trzecia reakcja, istotna odpowiedź Maryi, Jej zwyczajne «tak». Nazywa siebie służebnicą Bożą. «Niech mi się stanie według słowa twego» (Łk 1,38).

Emocjonalny aspekt tego momentu Bernard z Clairvaux przedstawił dramatycznie w jednym ze swych kazań adwentowych. Po upadku pierwszych rodziców cały świat zaległy ciemności, rozpostarło się nad nim panowanie śmierci. Wtedy Bóg szuka nowego sposobu przyjścia na świat. Puka do bramy serca Maryi. Potrzebuje ludzkiej wolności. Człowieka stworzonego jako istota wolna nie może odkupić bez dobrowolnego «tak» wobec Jego woli. Stwarzając wolność, Bóg w pewnym sensie uzależnił się od człowieka. Jego moc jest uwarunkowana niewymuszonym «tak» osoby ludzkiej"18.

Macierzyństwo Maryi wiąże się ściśle z Jej integralną i osobową wiarą. Cytowany wcześniej o. prof. Andrzej Napiórkowski wyjaśnia to następująco: „Dopiero w świetle wiary Maryi można właściwie uchwycić Jej macierzyństwo. Nie stanowi ono jakiegoś prywatnego stosunku do Syna, który tyczyłby się tylko Jej i Jego. Słusznie zauważa Joseph Ratzinger, iż wyjątkowość

18 Benedykt XVI, Jezus z Nazaretu. Dzieciństwo, s. 49-53. 
Chrystusa nie wymazuje indywidualnych relacji międzyludzkich przed Bogiem, gdzie przecież wszystkie osoby - lecz na różne sposoby - mogą być dla siebie nawzajem pośrednikami wobec Boga we wspólnocie z Jezusem Chrystusem ${ }^{19}$. Jeśli ta zasada odnosi się do wszystkich, to o wiele bardziej do Maryi, która odegrała wyjątkową i nie do przecenienia rolę w przyjściu Boga na świat. Historiozbawcze znaczenie Maryi uświadamiają teksty nowotestamentalne, które nie tylko ukazują Ją jako Matkę Jezusa, ale także obdarzają tytułem chrystologicznym Matki Kyriosa (por. Łk 1,43)"20.

\section{Wierzyć to pełnić wolę Bożą}

To „tak” Maryi dane aniołowi jest wyraźnym połączeniem wiary wiedzy z wiarą życia. To od Jej wolnej decyzji zależało zbawienie ludzkości przez Boga. Wiara wymaga więc rozumienia, ale stale winna być wspierana otwartością człowieka na Boga i zbawcze działanie w nim i przez niego. W tym przypadku była to najważniejsza decyzja, jaką podjęła Maryja - całkowicie zdana była na pełnienie woli Bożej. Dlatego każda próba rozumienia tego, co mówi Bóg do człowieka, wymaga od niego modlitwy, a więc dialogu z Bogiem, a nade wszystko wymaga otwartości na Boga. Ta otwartość na przyjęcie tego, co boskie, jest zawsze szansą dla człowieka i poszerza jego możliwości rozumowe, a więc poznanie przez wiarę. Ta wiara jest dana człowiekowi, ale musi być zgoda człowieka na jej przyjęcie.

${ }_{19}$ Por. J. Ratzinger, Maria. Gottes Ja zum Meschen, Freiburg i. Br. 1987, s. 471.

${ }^{20}$ A. Napiórkowski, Kościót w Maryi. Maryja w Kościele, s. 13. 


\section{Wielkość człowieka mierzona wiarą}

Należy jeszcze wrócić do wnikliwej analizy teologicznej Benedykta XVI i zatrzymać się nad jego interpretacją ostatniego zdania z opisu sceny zwiastowania Najświętszej Maryi Pannie. „Myślę - kontynuuje swoje rozważanie papież senior - że istotne będzie wysłuchanie również ostatniego zdania opowiadania Łukasza o zwiastowaniu: «Wtedy odszedł od Niej anioł» (Łk 1,38). Przemija wielka godzina spotkania z posłańcem Bożym, kiedy zmienia się całe życie, i Maryja znowu zostaje sama z zadaniem, które tak naprawdę jest ponad wszelkie ludzkie zdolności. Nie ma wokół Niej aniołów. Musi nadal kroczyć drogą prowadzącą przez wiele okresów ciemności - poczynając od przerażenia Józefa na widok Jej brzemienności, aż do momentu uznania Jezusa za szalonego (por. Mk 3,21; J 10,20), a wreszcie aż po noc Krzyża.

Ileż razy w tych sytuacjach Maryja wracała wewnętrznie do godziny, kiedy anioł Boży mówił do Niej, i na nowo słuchała i rozważała pozdrowienie: «Raduj się, pełna łaski!», i krzepiące słowa: «Nie bój się». Anioł odchodzi, misja pozostaje, a wraz z nią wewnętrzna bliskość Boga, wewnętrzne widzenie i dotykanie Jego bliskości"21.

Ta integralna wiara Maryi, wnikliwie przeanalizowana przez Benedykta XVI, jest dla każdego chrześcijanina wzorcowa. Bóg daje człowiekowi łaskę nadprzyrodzonego poznania, a więc przyjęcia tego, co przesyła w swoim zbawczym liście. Ta łaska wiary wydaje owoce dopiero wtedy, kiedy człowiek ją przyjmuje, czyli zdobywa się na całkowite zaufanie Bogu, który zawsze chce zbawienia każdego człowieka nie wbrew jego woli, ale z poszanowaniem jego decyzji i podjętej współpracy. Wiara wymaga rozumienia, które jest w zasięgu każdego człowieka otwartego w swoim poznawaniu tego, co boskie, i tego, co ludzkie. Wiara chrześcijańska jest więc w pełni aktem ludzkim i sposobem na życie, a nie

${ }^{21}$ Tamże, s. 54-55. 
dodatkiem do życia. Taka wiara jest dojrzałym i integralnym otwarciem się na odwieczne spełnienie się, czyli zbawienie.

Wielkość Maryi i Jej duchowe piękno zawiera się w integralnym akcie wiary, który nabierał mocy zbawczej we wszystkich wydarzeniach Zbawiciela, przy których Maryja nie tylko była obecna, ale w których uczestniczyła i które przeżywała. Jej wiara była wiarą życia, ale też wiarą wiedzy. Słusznie więc Kościół uważa Maryję za Matkę wiary, co oznacza, że od Matki należy się uczyć, jak żyć wiarą po chrześcijańsku. Z braku uczciwości wobec otrzymanej łaski wiary wypływa postawa niezrozumienia, nawet przez samych katolików, nieodzownej wartości wiary w pełnym rozwoju człowieczeństwa.

Maryja jako Matka wiary uczy człowieka otwartości na Boga, która stanowi też pełną otwartość na człowieka, na własne ludzkie spełnienie się. Przykład maryjnej wiary wzbogaca każdego, kto podejmuje drogę poznania przez wiarę. „W poznaniu przez wiarę - uczył św. Jan Paweł II - człowiek niewątpliwie przyjmuje za prawdę całą nadprzyrodzoną i zbawczą treść Objawienia, jednakże to przyjęcie za prawdę równocześnie wprowadza w głęboko osobowe odniesienie do samego objawiającego się Boga. Skoro właściwą treścią Objawienia jest zbawcze «samoudzielanie» się Boga, to odpowiedź wiary jest prawidłowa o tyle, o ile człowiek - przyjmując za prawdę ową zbawczą treść - równocześnie «cały powierza się Bogu». Tylko takie integralne «powierzenie się Bogu» ze strony człowieka stanowi odpowiedź adekwatną"22.

To, co usłyszała Maryja w Nazarecie od posłańca Bożego, przerastało możliwości poznawcze Jej czysto naturalnego rozu$\mathrm{mu}$, ale dzięki łasce Bożej zrozumiała, że to wszystko ma dotyczyć zbawienia wszystkich ludzi, dlatego uwierzyła Bogu i całkowicie oddała się pełnieniu Jego zbawczej woli.

22 Jan Paweł II, Co to znaczy wierzyć?, Warszawa 1988, s. 36. 


\section{Zakończenie}

Wiara jest dzisiaj lekceważona, a przecież należy do sfery poznawczej człowieka, i to rozumnej. Czasy postmodernistyczne zawężają wiarę do sfery irracjonalnej i najczęściej jest ona utożsamiana z wiarą religijną. Tymczasem istnieje przecież wiara naturalna, dzięki której człowiek rozwija i doskonali swoją wiedzę o sobie, otaczającym świecie, jak również wiedzę o Bogu. Dzięki wierze dowiaduje się o świecie nie tylko doczesnym, przyrodzonym, ale również nadprzyrodzonym.

Refleksja o Maryi i Jej wierze posłużyła do zasygnalizowania szerszego kontekstu poznawczego. Wiara religijna w rozumieniu chrześcijańskim nie może być ograniczana tylko do uczuć. Właściwie uczucia najmniej mają w niej do powiedzenia, ponieważ to, co człowiek poznaje przez wiarę, nie jest bezpośrednio dostępne ludzkim uczuciom. Dlatego nie należy spłycać tego tematu, ale starać się go pogłębiać i porządkować, ponieważ poznanie, czym jest wiara, należy do wymiarów sprawności umysłowej człowieka. Do tej sfery poznawczej należy też wiara religijna, a przede wszystkim chrześcijańska. Istotą takiej wiary jest osobowe zaangażowanie się człowieka, czyli przyjęcie Boga, który w pełni objawia się w Jezusie Chrystusie. Taka też była wiara Maryi, która uwierzyła całkowicie, dlatego została nazwana przez Elżbietę błogosławioną.

\section{Blessed, who believed... Faith of life and faith of knowledge}

Faith nowadays is disrespected, even it belongs to the cognitive domain of a man, the man as the rational being. The post-modernism times narrow faith to the irrational sphere, and faith is often equated with religious faith. 
However, there is natural faith, thanks to which the human being develops and improves knowledge about himself, the surrounding world, as well as knowledge about the God. Thanks to faith, man learns not only about earthly and worldly, but also about the supernatural world. Thoughts about St. Mary and her faith served to emphasise the broader cognitive context. Religious faith, according to the Christian teachings cannot be limited to the only sphere of feelings. Feelings actually, have the least to say because what the man gets to know through faith is not directly available to the human feelings, therefere it is not apropriate to make this problem superficial, but there is a need to deepen it and to put in the right order. It is because to get to know what is faith depends on the level of mental capacity of a man. To this cognitive sphere, the religious faith also belongs, and especially the Christian faith. The essence of this faith is the personal commitment of the man, it means acceptance of the God, who reveals fully as Jesus Christ. Faith of St. Mary was like that, St. Mary who believed entirely, therefore by St. Elisabeth she was called the blesssed one. 